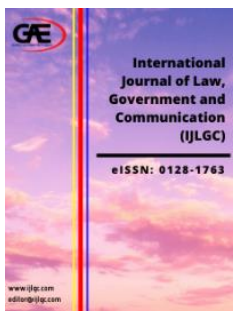

\author{
INTERNATIONAL JOURNAL OF LAW, \\ GOVERNMENT AND COMMUNICATION \\ (IJLGC) \\ WWW.ijlgc.com
}

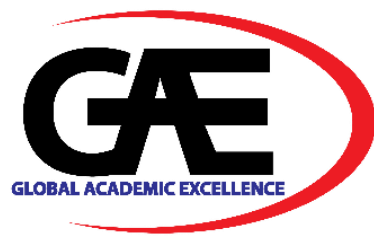

\title{
BATIK MOTIFS AS A MEANS OF BUILDING FOR PEACE: JAVANESE PERSPECTIVE
}

\author{
Bani Sudardi $1^{*}$ \\ 1 Cultural Studies Study Program, Sebelas Maret University of Surakarta \\ Email: banisudardi@yahoo.co.id \\ * Corresponding Author
}

\section{Article Info:}

\section{Article history:}

Received date: 01.10 .2017

Revised date: 10.10 .2017

Accepted date: 15.08.2021

Published date: 01.09.2021

\section{To cite this document:}

Sudardi, B. (2021). Batik Motifs As a Means of Building For Peace: Javanese Perspective. International Journal of Law, Government and Communication, 6 (25), 09-16.

DOI: $10.35631 /$ IJLGC.625002.

This work is licensed under $\underline{\text { CC BY } 4.0}$

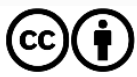

\begin{abstract}
:
Batik is an Indonesian masterpiece with a variety of motifs. Among the motifs are expressions of human local genius, ideas, and community life expression. Hope, peace, and history were all expressed through batik motifs. The idea of peace brought by batik motifs is discussed in this paper. The batik's expression of peace has been reflected in its production. Batik cloth is created through a lengthy process. The makers can initiate by sketching motifs with a pencil, and then use wax to illuminate the motifs. The wax serves to both block and color the material. Waxing is a time-consuming process for blocking and coloring the fabric and completing a piece of batik cloth requires patience. Peace can only be achieved through patience, which can be seen in batik designs. Many symbols of peace can be found in batik motifs. The symbols reflect the harmonic situation with (1) God, (2) nature, and (3) creatures. The semen motif is associated with a harmonious relationship with God representing shaped like a God (deva) palace, symbolizing both the human and the divine. Batik always illustrates nature, and the parang motif illustrates the human-mountain-ocean bond. To reach the sea, the mountain must have a slope. In Javanese, pereng or parang refers to a slope. The Sekar Jagat motif (universe flowers) portrays a human in relation to the world or universe. The Truntum motif describes harmony with the night sky, stars, and flowers. There are patterns in the motif that are mostly taken from nature. I.e., the ceplok pattern adopts flowers in bloom, the lereng (slopes) pattern adopts a downhill road, the patterns semen adopts a plant in its first growth stage, the lunglungan pattern adopts tree vines, and the buketan pattern adopts flower or foliage arrangement. When humans have a harmonious relationship with nature, peace is formed. As a result, various batik motifs convey a message of world peace. Batik is a type of media used to promote peace in the world. Harmony with God, nature, and one another exemplifies peace.
\end{abstract}

Keywords:

Batik Motif; Peace; Media 


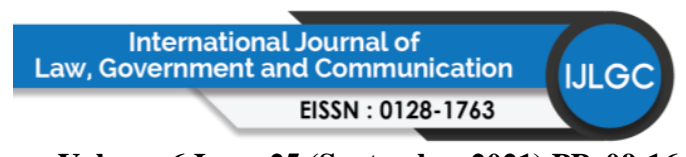

Volume 6 Issue 25 (September 2021) PP. 09-16

DOI 10.35631/IJLGC.625002

\section{Introduction}

Batik has become a world-renowned Indonesian masterpiece. Batik is a beautiful textile art that has spread all over the world. UNESCO has designated batik, particularly batik from Yogyakarta and Surakarta, as a Representative List of the Intangible Cultural Heritage of Humanity. The advancement of science, technology, and art during the globalization era has had a significant impact on the evolution of traditional batik. Changes in people's perceptions of the manufacturing process led to changes in the batik-making process. Batik making used to be done entirely by hand, and it was a laborious process (Indarmaji, 1983; Trixie, 2019). The process of making batik has evolved from writing and stamping to being carried out with a printing machine as a result of technological advancements. This modern batik becomes batikpatterned textiles / batik printing, not batik cloth. Traditional batik (written and stamped batik), which is rich in local wisdom values, must be passed down to future generations so that batik can become the host in their own country.

Talking about traditional batik, which is inextricably linked to its symbolic meaning. Humans, according to Ernest Cassirer (1944: 40), are animal symbolicum, or creatures capable of understanding and employing symbols (signs). Humans can also create and comprehend the meaning of these symbols, allowing them to be used as norms, guides (instructions) to good behavior and deeds. Traditional batik, as a cultural heritage, contains intriguing wisdom values that should be investigated in terms of the process, motif, color, ornamentation, and function of a piece of batik.

The majority of traditional batik motifs come from nature and the surrounding environment. This is the artist's interpretation of his or her religion and beliefs, which are typically kept confidential (Indarmaji, 1983: 12). Batik motifs also contain symbolic-magical values for religious/belief functions, as well as aesthetic values for decoration. The influence of religion and belief can be seen in the development of batik in Indonesia, which prioritizes the meaning of respect for the gods. At the time, batik was the exclusive clothing of the upper class and nobility. Batik patterns with symbolic meanings were preferred by the nobles, who believed that the glow of batik would create a religious-magical atmosphere. This is evidenced by beliefs that emphasize the form of belief and religion. As a result, a number of batik motifs, particularly those with high philosophical meaning, have been declared as prohibited patterns for the wider population (Condronegoro, 1995: 18).

Apart from this issue, batik appears to have a plethora of issues in human life. Hope, peace, and history were all expressed through batik motifs (Josefine, 2019). A piece of batik art cloth has a story to tell. The stories behind each of the batik motifs are unique. The story is based on a wide range of Indonesian cultures. The story Adiparwa sub Garudeya, for example, inspired the gurdan motif or eagle motif (Garuda story). Other motifs, such as the watu pecah (broken stone), appear to have been inspired by the Dutch colonial era sweatshop story. The Java community was under pressure at the time to assemble the stones for road construction. Meanwhile, the Pekalongan batik motif brings up Hansen and Gratel, and Snow White is a Western story influenced by Dutch culture. Because it was developed by Dutch people living in coastal Pekalongan between 1840 and 1940, it is commonly referred to as Dutch batik (batik Belanda) (Sudardi, 2017). 


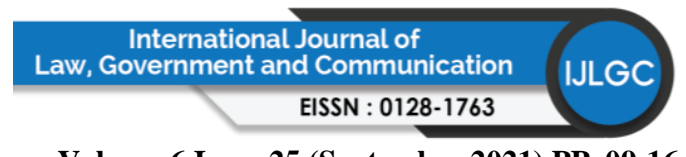

Volume 6 Issue 25 (September 2021) PP. 09-16

DOI 10.35631/IJLGC.625002

There have been many previous studies that examined the philosophical meaning of patterns and motifs in batik, including Nursalim and Sulastianto (2016) deconstructing the meanings of the Cirebon Palace batik motifs, according to which the symbolic and philosophical meanings contain moral messages. Other studies that enriched the discussion of the present among others; systematic analysis of Javanese symbols on batik motifs (Hidajat, 2004), cultural identity in traditional and contemporary batik symbols (Darmaputri, 2015), and the symbolic value of Sido Mukti's batik in life, which leads to better social cohesion by serving symbolic values of the batik (Jumariah, 2019). Tjahjaningsih, et al. (2019) studied creative techniques of Semarangan batik motif designs where both artists and developers produced the batik motif designs according to current trends and customers' interests without neglecting the cultural aspects. Trixie (2020) discovered the reasons underlying the UN recognized batik as a tangible heritage as well as cultural identity for Indonesian people.

These previous studies enriched the descriptions as well as a gap that needs special attention discussed in this paper. Bearing in mind, the existence of batik stems from regional cultural roots that are rich in local wisdom, messages, and hopes for a good, harmonious, and prosperous life. This paper seeks to investigate batik as a medium that helps people build peace. This paper also discusses the process of making batik, as well as the motifs and their meanings, all of which are intended to promote peace.

\section{Method}

This study was designed with a qualitative descriptive research model because the results of this study were in the form of exposure and description of the symbolic meaning of batik motifs. In this qualitative study, the methods of observation, interviews, and documentation were used. Empirical tests were carried out in this study, namely by direct researchers looking for data through observation by involving themselves in the research subject. The study took place around Surakarta, Central Java. The subjects of this study are the producers, the worker, academic, family of king, students, and so on. We also have an observation in many places. Documents as books are also as our data source. In analysing data, we used integrative analysis (Miles and Huberman, 1992).

\section{Results snd Discussion}

\section{Making Batik}

Batik is a kind of painting art that need contemplation and composure. Batik can only be made well on peace time. So, it can be concluded that batik is a symbol of peace. The first process in making batik is by making pattern in a piece of white cotton. It needs contemplation to make pattern. The ideas usually are from nature (flora and fauna). There are three kind in processing batik, (1) traditional process, (2) kesikan process, (3) pesisiran process (Doellah, 2002:13). Principally, the three processes are in the same, but there are some variations and then to be their specific way. The first process is by making pattern with pencil in the white cotton. The pattern then filled with hot liquid wax. The tool to fill the pattern is canthing. Actually, this is the activities called mbatik means making batik. After forming the pattern, the space left to be white area will be blocked by liquid wax. It is called nembok (block). The blocked will be still in white colour at the end of the making batik process. 


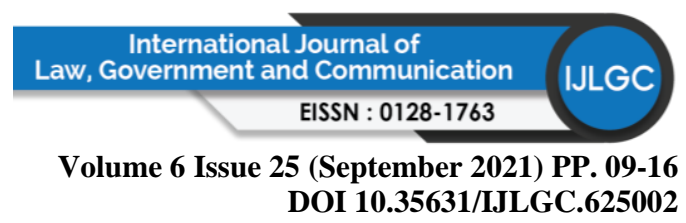

The next process is to dye or to give basic colour. The cotton with the wax pattern is dyed in the blue liquid colour to make the cotton to be blue. The step called medel. The next step is to choose the space in the cotton that will be in brown colour. Brown is standard colour of traditional batik. Some of the cover wax was scraped. After scraping, the cotton was washing to eliminate the rest of the wax. The step called ngerok (scraping). The next is blocking the area that will still in blue by wax. This process called mbironi means select the blue area. After it, the cotton is dyed in the brown colour liquid called soga. It is a specific colour in batik. The dyeing will make the cotton dominated by brown colour. The last step is removing all of the wax by hot water. Then, cotton is dried the then be deposed for the next use. The process of making batik by kesikan technique is after dyeing with blue colour liquid (medel), all the wax was removed. Then, the area that will be in blue or white, this area blocked by wax. This step called ngesik, so we call this process as kesikan. The last steps are dying the cotton in the brown colour liquid $(\operatorname{sog} a)$ and remove all the wax and continued to be drying and deposited.

The process of making batik by coastal technique or Pekalongan technique by colouring with special tool canthing colet on the cotton. The tool use to give colour, not by dyeing. So, this technique is also called colet technique. The area that coloured by canthing colet then covered by wax. Because it is using canthing colet, so the technique also called colet technique. The area coloured by colet then blocked by wax and then dyed in the basic colour liquid, usually blue. After it, all wax then removed. After all the wax removed. The coloured area and white area blocked again by wax to cover white spot called granit area outside the pattern by little circle called granit. So, it is 3 ways to make batik. All of the way needs along time and peace situation. So, making batik is a symbol of peace. Without peace, someone can't make a beautiful batik. It reflected the patience. Peace must be built in patience situation. Batik motifs reflect the peace. Some people said that batik is a media of meditation

\section{Batik Motif and Harmony}

One aspects of peace is harmony. Batik motifs reflect in the harmonic situation with (1) God, (2) harmonic situation with nature, and (3) harmonic situation with creatures. These situations describe in the motifs. Meru motif is a symbol of harmonic situation with God. Meru is in the form of God (deva) palace. It symbolized the human and the God. Meru imitated in the Javanese palace (kraton). The kraton is a symbol the unity of God and human. It is as a symbol of jagad gedhe (big universe). The human is a symbol of little universe (jagad cilik). The people who close the God, will feel the peace of the world. The peace was formed when the human has harmonic relation with the nature. Javanese are a religious people. Before the coming of Islam, Javanese is Buddhism and Hindu. The traces of these religions are still existing in the Javanese daily life. Wayang which contains Hindu's message is still popular until now. Mahabharata and Ramayana are expressed in many forms of arts, included batik. Batik expressed the harmonic situation with God in many ways. Actually, batik is a kind of figurative picture. According to Islamic law, people not allowed to picture life creatures. So, batik, especially classic batik always describes life creature in figurative style. It is a symbol to make a peace to the God Law according to Islam. According Hindu, Gods live in khayangan or place in the top of Mahameru mountain. There is a form of a picture called Meru in the traditional picture of Javanese. 


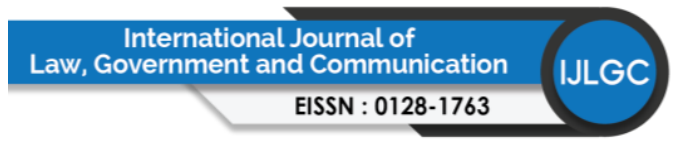

Volume 6 Issue 25 (September 2021) PP. 09-16

DOI 10.35631/IJLGC.625002

\section{Batik Motif and Peace}

Batik has a hope. Someone who uses a certain batik motif sometimes has a hope. For example, there are many kinds of sidomukti motif. The meaning of sidomukti is to be honoured or become honoured. This motif uses in wedding ceremony. By using sidomukti motif, the hope they can gain their idea to honoured couple (Handayani, 2002). Batik always describes the nature. Parang motif is a description the unity of human with mountain and ocean. The mountain requires slope to reach the sea (Sarwono. 2004). Pereng or parang means slope in Javanese. Actually, this motif is a symbol of inner peace. The motif created by Sultan Agung, the King of Mataram in the 17th century. The background to create it is to honour his ancestor, Panembahan Senopati who has founded the Mataram Kingdom. The inspiration in founding Mataram Kingdom came from the place Parangkusuma, in the South Javanese coastal. One day Panembahan Senopati has a meditation di Parangkusumo. A fairy came to him, she expressed that she had a lower power to him. So, the fairy, Ratu Kidul, give up to him and to be his magic wife. Actually, it is as a symbol of self-control of Panembahan Senopati how to build a peace. In pupper it called as "mboten sarana ginebag ing prang hamung kayungyun marganing kautaman" (not defeated by war, but just falling in love with the honesty". To memorize this meeting, Sultan Agung made a motif parang, from the name of Parangkusuma. It is also symbol of peace between physic and psyche.

Sekar Jagat motif (the flowers of the universe) is the image of human in relation to the world or the universe. Actually, sekar jagat motif is a mixing of many motifs in the piece of cotton. It expressed the beauty of the world. The beauty is in parallel with the peace. No peace no beauty. Actually, the sekar jagat motif is not old motif. It arises in the modern era when batik has flowed outside the wall of the palace. Truntum motif describes harmony with the night sky, stars and flowers. In motif there are patterns that mostly adopted from nature. Truntum motif means "grow of the love. There is a romantic story about the arise of truntum motif. The King of Surakarta, Pakubuwana III once day angry to his wife, Raden Ayu Beruk. The wife was so sad about it and decides to go to her parent's house. To loose her sad she made a batik with star and flower in the black ground. It symbolized her sorrow along the night and the day. One day, Pakubuwana knew about the new motif, and he asked who has made this motif. Someone told that this motif was from her wife. He was so excited and looses his angry. He asked his wife to finish the batik and then he brought his wife to the palace. The love was growing, and the king named the motif truntum, the grow of love. The motif became the symbol of the grow of love and people give the motif to use in wedding ceremony.

The other pattern of batik is ceplok. The meaning of ceplok is a circle. It associated the circle form of flower. The pattern adopts the flowers in bloom. It is truly to express the beauty and peace situation. Ceplok pattern inspired by the blossom of the nature. Pattern lunglungan adopt a tree vine. It is symbol of fertility. Buketan pattern adopt arrangement of flowers or foliage. The peace was formed when the human has the harmonic relation with the nature. Batik always describes the nature. It can be concluded that in the motif there is a message to build harmony with the world. Batik is a media in campaigning for peace in life. Peace is illustrated by harmony with God, nature, and each other. Batik motif that inspired by plant is semen. It means "grow". This motif contain ornament formed feet four animal, bird, creep pant, a building, a mountain, and wings of eagle. This motif expressed of harmonic situation to the God. Semen has some meaning to the ilir-ilir song. The theme of this song is about the grow of rice. It has connection to the agricultural culture of Javanese society. In the other hand, semen also has 


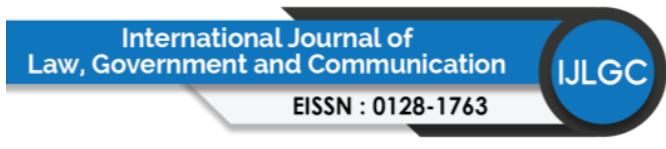

Volume 6 Issue 25 (September 2021) PP. 09-16

DOI 10.35631/IJLGC.625002

some meaning to the mountain figure in puppet show called "gunungan" (mountain alike). All of these have fertile themes. Every ornamental form in the semen motif has a symbolic meaning to the belief of the life (Pujiyanto, 2010:46). It has connection to the sacred belief. The elements of the semen motif are:

\section{Plant}

Plant is symbol of fertile in the context of agricultural culture. The character of fertile land is many plants grow well. For farmers, fertile land is very important to develop their job. It be expressed in Javanese idiom: "subur makmur gemah ripah loh jinawi" "fertile and prosperous", in the other idiom "thukul kang sarwa tinandur, bathi kang sarwa tinuku" (all plant grow well, all commerce get good profit". It means that plant build a peace to make fertile and prosperous

\section{Meru}

Meru is abbreviation from Mahameru. It is Himalayan Mountain in India. But, according to Javanese belief, Gods had brought this mountain to Java and called Semeru Mountain. Semeru Mountain is place for God. Meru is symbol of peace, high, and good. There is a wellspring in Meru called kula-kula. It is a magic wellspring. Someone who drinks its water will not die. There is also sandilata tree which can make dead person to live again (Pujiyanto, 2010:47).

\section{Palace}

In the top of Semeru mountain, Gods live in their palace So in the motif we find a building as a symbol of the God Palace called "kahyangan". Kahyangan mean "place of Hyang or God". So, the palace in the semen motif describes the peace of the God. The peace of the God imitates to the place of the king. According to the old Javanese, the king is a manifestation of the God. It is called as "dewa raja" or "king as a god".

\section{Eagle Wing}

Eagle wings are a symbol of the existence of Garuda. It is a mythological bird in Mahabharata. Garuda is a symbol of the loyalty to mother. Minatare is the mother of Garuda. Winata fallen into slavery. Garuda tried to release his mother from slavery. Many heroics afford took place in his mission. And at the end, Garuda had succeeded in release his mother from slavery. In the one of episodes of Garuda Story, there was a story about Garuda and Vishnu. Vishnu permits Garuda that he wants to ask Garuda just a thing. Garuda agree to this, and Vishnu said that he asks Garuda to be his vehicle. Garuda was shocked, but he can't avoid it because he had promised to Vishnu's about it. So, the existence of garuda means the existence of Vishnu. According to Javanese belief, the king is the reincarnation of Vishnu, the use of gurdan motif (wing eagles), mean the existence of Vishnu.

\section{Birds}

Bird is a symbol of upper worlds. Birds are a symbol of beautifulness. Birds are also a symbol of life. In Javanese belief, birds also a symbol of freedom from physical life, symbol of soul ad the nearness to God.

\section{Four Feet Animal}

Four feet animal is a symbol of forest. It is a symbol of completeness. The God in the mountain and mountain have forest. The motif that has free style is alas-alasan motif (forestry motif). The motif describes about the situation in the jungle or forest. The differences this motif with 


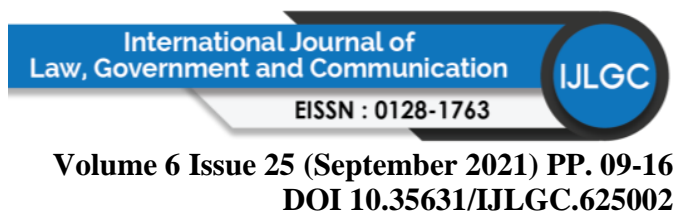

semen motifs are that the motif painting more animals. In this motif, there are also stylization of ocean, cloud like decoration, and mythology animals. There are many animals in alas-alasan motif. The animals can be divided in three as a symbol of three world according Hindu's doctrine, there are (1) upper world, (2) middle world, and (3) under world. The concept expressed in batik motif as describe in the table below

\begin{tabular}{|l|l|}
\hline \multicolumn{1}{|c|}{ Worlds } & \multicolumn{1}{c|}{ Symbols } \\
\hline Upper World & $\begin{array}{l}\text { Cloud, bird, eagle, butterfly, fire, the chair of the king (dampar), flying } \\
\text { animal }\end{array}$ \\
\hline Middle World & Tree, meru, building, four feet animal, land animal \\
\hline Under World & Ship, ocean, fish, snake, dragon \\
\hline
\end{tabular}

Alas-alasan motif describes the specification of forest. It describes about the harmonic situation di the forest. It means as the symbol of prosperity and fertilization. Although, there are not good animals that destroy or kill other animal as locust and tiger, but there is also good animal as horse, snake, butterfly, and so on. Batik describes all in harmonic situation and no painting about eating each other. Although, in the reality animal often eat other. It is truly of inner concept about harmony, about peace (Sarwono. 1997) According to Hindu's concept, alasalasan pattern describe about three world (triloka), water, land, and air. There are many elements in the alas-alasan motif. Each element consists of the meaning. Here it is the meanings of every element in the alas-alasan motif as described in Table 2

\begin{tabular}{|l|l|}
\hline \multicolumn{1}{|c|}{ Elements } & \multicolumn{1}{c|}{ Meanings } \\
\hline Sawat (eagle wing) & A symbol of the sun, upper world \\
\hline Meru & A symbol of gods (deva) place, upper world \\
\hline Life tree (pohon hayat) & A symbol of life \\
\hline Fire & A symbol the power and devotion \\
\hline Bird & A symbol of happiness and long life \\
\hline Four feet animal & A symbol of happiness and long lif \\
\hline Ship & A symbol of struggle of life \\
\hline A chair of king (dampar) & A symbol magic power, the place of king \\
\hline Heirloom (pusaka) & $\begin{array}{l}\text { A symbol of divine revitalization, happiness, and } \\
\text { peace }\end{array}$ \\
\hline Dragon & A symbol of magic power and fertile \\
\hline Butterfly & $\begin{array}{l}\text { A symbol of magic power and fertile Butterfly A } \\
\text { symbol of happiness and lucky }\end{array}$ \\
\hline
\end{tabular}

\section{Conclusion}

Batik actually is an art with the cotton as its media. Batik is an art full with symbol and contemplation according the owner. Batik expressed a message of peace. It can be concluded from many aspects of batik. The process of making batik needs many steps and some of the steps need a contemplation. The motif of batik expressed a peace world; there is love, contemplation, many symbols of happiness, lucky, and the power of gods. Batik expressed a harmonic situation between god, man, animal, and three. No war or disorder situation in the batik motifs. 


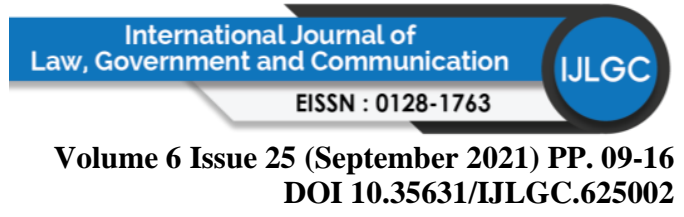

\section{Acknowledgements}

The authors wish to express their gratitude and credits to the Higher Education Board (Dikti), Indonesia which has funded the research scheme of Post Graduate Research Grant.

\section{Reference}

Cassirer, Ernst. (1944). An Essay on man an introduction to a philosophy of human culture. Yale \& New Heaven: Yale University Press

Condronegoro, M. S. (1995), Busana Adat Keraton Yogyakarta, Makna dan Fungsi dalam Berbagai Upacara. Yayasan Pustaka Nusantara, Yogyakarta.

Darmaputri, G.L. (2015). Representasi Identitas Kultural dalam Simbol-Simbol pada Batik Tradisional dan Kontemporer. Commonline Departemen Komunikasi, 4 (2), 2015

Djoemena, Nian. (1990). Ungkapan Sehelai Batik. Jakarta:Jambatan.

Doellah, H. Santosa. (2002). Batik: The Impact of Time and Environment. Surakarta: Danarhadi.

Handayani, Sarah R. (2002). Makna Simbolis Pola Sidomukti dalam Perkawinan Adat Jawa di Surakarta. Surakarta: Fak. Sastra dan Seni Rupa, UNS.

Hidajat, R. (2004). Kajian Stukturalisme-Simbolik Mitos Jawa pada Motif batik Berunsur Alam. Bahasa dan Seni, 32 (2), Agustus 2004

Indarmaji, (1983), Seni Kerajinan Batik. Dinas Pariwisata Daerah Isti mewa Yogyakarta.

Josefine, V.M. (2019). Indonesian Cultural Diplomacy through UNESCO in Winning Batik as Intangible Cultural Heritage (2008-2009). (A Thesis). Faculty of Humanities, International Relation Study Program, President University

Jumariah, (2019). Nilai Simbolis dan Filosofi Kain Batik Sido Mukti dalam Kehidupan. Jurnal Socia Akademika, 20, (5), Mei 2019.

Miles, M. dan Huberman, A. M.(1992). Analisis Data Kualitatif. [Trans].Jakarta: UI Press.

Pujiyanto. (2010). Batik Keraton Kasunanan dan Mangkunegaran Surakarta. Yogyakarta: Kendil.

Nasution. (1992). Metode Penelitian Naturalistik Kualitatif. Bandung: Tarsito

Nursalim, A. \& Sulastianto, H. (2016). Dekonstruksi Motif Batik Keraton Cirebon: Pengaruh Ragam Hias Keraton pada Motif Batik Cirebon, Jurnal Penelitian Pendidikan 16, (1),

Sarwono. (1997). "Filsafat Hidup Orang Jawa dan Simbolisme dalam Motif Batik", Haluan Sastra Budaya, 31 (15) Juli 1997.

Sarwono. (2004). "Pendekatan Hermeneutik Simbolisme Motif Parang". Etnografi: Jurnal Penelitian Budaya Etnik, 04 (5), Juni 2004

Trixie, A.A. (2020). Filosofi Motif Batik sebagai Identitas Bangsa Indonesia. Folio - Journal of Fashion Product Designs and Business, 1 (1), (2020), https://journal.uc.ac.id/index.php/FOLIO/article/view/1380/1148

Tjahjaningsih, E., Handayani, D., Santosa, A.B, \& Utomo, A.P. (2019). "Creative Technique of Contemporary Batik Motifs Based on History". International Journal of Organizational Innovation, 12 (3), January 2020 